\title{
Wat zien gebruikers aan effecten van IFRS?
}

\begin{abstract}
Ger den Ouden
SAMENVATTING Gebruikers van jaarrekeningen vragen zich af wat implementatie van IFRS voor hen betekent. Dit artikel vermeldt de bevindingen van een inventariserend onderzoek naar de mededelingen door ondernemingen over de gevolgen van IFRS voor het beeld dat de jaarrekening biedt. Een kleine meerderheid van de ondernemingen verstrekt gegevens over de gevolgen van invoering van IFRS, daarbij zijn verstrekkers van kwantitatieve informatie in de minderheid.
\end{abstract}

\section{Inleiding}

Over boekjaren die op of na 1 januari 2005 beginnen moeten Nederlandse beursgenoteerde ondernemingen rapporteren op basis van International Financial Reporting Standards (IFRS). Implementatie van IFRS impliceert een fundamentele wijziging in het denken over verslaggeving. Hoogendoorn (2004) spreekt over 'de grootste omwenteling ooit in de financiële verslaggeving van ondernemingen'. Bovendien wordt de financiële verslaggeving door ondernemingen met de invoering van IFRS strakker gereguleerd dan thans in Nederland het geval is. De overwegingen die hebben geleid tot toepassing van IFRS zijn onder meer de 'verbetering van de vergelijkbaarheid van jaarrekeningen van beursgenoteerde ondernemingen' en 'bij te dragen tot de efficiënte en kosteneffectieve werking van de kapitaalmarkt' (Verordening EG, 2002).

Invoering van IFRS heeft tot gevolg dat de jaarrekening een ander beeld zal tonen dan tot dusver (zie ook Vergoossen, 1999). Het is rapportage op basis van

G.J. den Ouden is werkzaam bij Research Institute van NIBCapital Bank. Dit artikel is geschreven op persoonlijke titel. De auteur bedankt I.Blij voor zijn waardevolle suggesties, alsmede de redactie van dit blad voor hun nuttige opmerkingen. andere grondslagen over dezelfde werkelijkheid. Veel gebruikers van jaarrekeningen vragen zich daarom af wat IFRS voor hen betekent. Wat is bijvoorbeeld het effect op veel gehanteerde ratio's, zoals eigen vermogen in percentage van het balanstotaal, en kengetallen, zoals koers/winst-verhouding? Ook missen gebruikers 10-jarige cijferreeksen op vergelijkbare basis. Dat kan leiden tot onzekerheid bij het nemen van vermogensallocatiebeslissingen, voorzover deze mede worden gebaseerd op financiële verslagen. De kans dat een verrassingseffect optreedt is groter, als de verschillen met de huidige opstellingen substantieel zijn.

Gebruikers van jaarrekeningen wensen informatie die de verschillen tussen het oude en nieuwe regime kwantificeren, verduidelijken en toelichten. Een illustratie hiervan is te vinden in Het Financieele Dagblad van 23 januari 2004, waarin een artikel stond met de kop: 'Analist wil zicht op gevolg nieuwe boekhoudregels'. De boodschap van dit bericht was: Het niet tijdig geven van inzicht in die gevolgen kan leiden tot negatieve reacties op de beurs. De kans op een dergelijke reactie is niet denkbeeldig. Als voorbeeld kan daarbij Ahold dienen, dat in de jaarrekening 2001 een aansluiting tussen nettoresultaat en eigen vermogen volgens US GAAP en NL GAAP verstrekte. Het resultaat volgens NL GAAP bleek $€ 1$ miljard hoger dan volgens US GAAP. Het Financieele Dagblad van 9 april 2002 meldde dat 'beleggers geschrokken waren door de grote verschillen .... In twee dagen zakte de aandelenkoers met circa $10 \%$. Het verrassingseffect zat in de onverwacht grote omvang van het verschil. In voorgaande jaren was de aansluiting ook gepubliceerd, maar was het verschil minder groot.

Gebruikers hebben tijd nodig om de effecten en consequenties van de veranderingen te verwerken. Evenals ondernemingen tijd nodig hebben om zich voor te bereiden op de implementatie van IFRS, hebben gebruikers daar behoefte aan. Gebruikers dienen een nieuw toetsingskader te vormen en nieuwe referentiewaarden te definiëren. Het is daarom een goede 
zaak dat het Euronext marktreglement in Rule 7203/3 verlangt dat ondernemingen uit het NextEconomy en NextPrime segment uiterlijk in het halfjaarverslag 2004 'een toelichting opstellen met een beschrijving van de verwachte effecten op de beginbalans en op de resultaten over de afgelopen periode van de overgang van de huidige grondslagen voor waardering en presentatie op IFRS'.

Dit artikel gaat na of beursgenoteerde ondernemingen in het halfjaarbericht 2004 gegevens hebben verstrekt omtrent de gevolgen van implementatie van IFRS op beginbalans en resultaten om gebruikers in staat te stellen een nieuw referentiekader te vormen.

In paragraaf 2 wordt een theoretisch kader geschetst. Paragraaf 3 beschrijft allereerst de onderzoekspopulatie. Vervolgens biedt paragraaf 4 op basis van het onderzoek een overzicht van de bevindingen. Paragraaf 5 schetst een beeld van de meest voorkomende posten in de jaarrekening die worden beïnvloed door de invoering van IFRS. Dit artikel sluit af met een samenvatting en conclusies in paragraaf 6 .

\section{Theoretisch kader en regelgeving}

In 2002 is in een Verordening van het Europees Parlement en de Raad $^{1}$ het besluit vastgelegd om met ingang van het boekjaar 2005 alle beursgenoteerde ondernemingen te verplichten tot het opstellen van hun geconsolideerde jaarrekening op basis van IFRS. Dit overigens alleen voorzover de standaarden door de EU zijn goedgekeurd voor toepassing.

De bespreking van de gevolgen van IFRS concentreert zich in de Nederlandse vakliteratuur vooral op reële waarde in de jaarrekening en op specifieke onderwerpen. Zo zijn artikelen verschenen over het waardeconcept binnen IFRS, bijzondere waardevermindering van vaste activa, de verwerking van financiële instrumenten in de jaarrekening en waarderingsaspecten van de goodwill impairment test. Camfferman en Van der Wel (2003) gaan bijvoorbeeld in op de plaats van reële waarde in de regelgeving. Daarnaast wordt aangegeven dat de ontwikkeling in de richting van het toepassen van fair value accounting gevolgen heeft voor het beeld van de jaarrekening. Zo meldt Hoogendoorn (2003b) hierover onder meer: 'Een direct gevolg is ook dat de jaarrekening er anders uitziet, waarbij voor ondernemingen vooral de volatiliteit een punt van zorg is.' In Het Financieele Dagblad van 2 juni 2003 merkt Vergoossen op: 'De introductie van de IFRS vereist niet alleen een attitudeverandering van ondernemingsleiding en controlerend accountant, maar ook van de gebruikers van de verslaggeving. [...] Toepassing van de IFRS leidt tot grotere schommelingen in de gepresenteerde winstcijfers, doordat vaker moet worden gewaardeerd op basis van reële waarden en de strengere eisen aan de vorming van voorzieningen. Hierdoor zou, in de ogen van ondernemingsleidingen, de onzekerheid bij aandeelhouders, analisten en andere belanghebbenden over het reilen en zeilen van ondernemingen toenemen.' Daarnaast is er in de literatuur aandacht voor vraagstukken die als gevolg van implementatie van IFRS opkomen bij de controle van jaarrekeningen (Hoogendoorn, 2003a) alsmede bij het toezicht op financiële verslaggeving (Marseille en Koster, 2002).

Bezien vanuit gebruikersperspectief biedt dit een fragmentarisch beeld. De vraag welk totaalbeeld blijkt uit een op basis van IFRS opgestelde jaarrekening, krijgt relatief weinig aandacht. Maar dat niet alleen, ook de behoeften van gebruikers lijken op de achtergrond geraakt (Den Ouden, 2004). Gebruikers van jaarrekeningen trachten de daarin verstrekte gegevens in perspectief te plaatsen. Het Conceptual Framework, in het Nederlands aangeduid met Stramien ${ }^{2}$, vermeldt onder meer het volgende: '... Gebruikers moeten ook in staat zijn de jaarrekeningen van verschillende ondernemingen onderling te vergelijken, teneinde hun relatieve financiële positie, resultaten en wijzigingen in financiële positie te beoordelen. ...' (Stramien paragraaf 39). In de onderhavige situatie van implementatie van IFRS is voor gebruikers van jaarrekeningen van belang, dat een adequate beoordeling van de ontwikkelingen in financiële posities en resultaten van ondernemingen mogelijk blijft. Invoering van IFRS heeft tot gevolg dat de jaarrekening een ander beeld zal tonen dan gebruikers tot dusver gewend waren. In dat licht bezien is ook de volgende paragraaf uit het Conceptual Framework van belang: 'Een belangrijke stilzwijgende consequentie van het kwalitatieve kenmerk van vergelijkbaarheid is, dat gebruikers worden geïnformeerd over de grondslagen van waardering en resultaatbepaling die bij de opstelling van de jaarrekening worden toegepast, van enige wijzigingen in die grondslagen en van de invloed van zodanige wijzigingen. ...' (Stramien paragraaf 40). Indien uit de jaarrekening op basis van IFRS een ander beeld naar voren komt dan gebruikers gewend zijn, biedt het kunnen vormen van een referentiekader door onderlinge vergelijking van jaarrekeningen van ondernemingen uit dezelfde bedrijfstak een handvat. Immers op deze wijze verkrijgen gebruikers van jaarrekeningen enige vorm van criteria waaraan de relatieve prestatie van een onderneming kan worden getoetst. 
Zoals voor externe verslaggeving in het algemeen geldt, is dit mutatis mutandis in de huidige overgangssituatie eveneens van toepassing: 'Organisaties zullen hun aanbod van informatie moeten afstemmen op de vraag naar informatie die onder buitenstaanders leeft. Als die afstemming achterwege blijft ontstaan er fricties. Frictie kan algemeen van aard zijn, zoals maatschappelijke kritiek, negatieve reacties in de pers. Maar frictie kan ook meer specifiek bij een bepaalde groepering ontstaan, zoals een ongunstige koersreactie, problemen met de financiering of arbeidsonrust.' (Klaassen, Hoogendoorn en Bak, 2001, p. 24).

Op grond van eerder onderzoek (Botosan, 1997; Botosan en Plumlee, 2002; Francis et al., 2004; Holterman, 2002) mag worden verwacht dat ondernemingen, in de vorm van lagere vermogenskosten, voordeel hebben bij het verschaffen van extra informatie. Naar analogie van hetgeen het Conceptual Framework stelt omtrent de afweging tussen relevantie en betrouwbaarheid, geldt in de huidige situatie dat het omwille van het tijdig verschaffen van informatie, noodzakelijk kan zijn om hierover reeds te rapporteren voordat alle aspecten bekend zijn. Hierdoor wordt weliswaar de betrouwbaarheid aangetast, maar, 'indien de berichtgeving wordt uitgesteld tot alle aspecten bekend zijn, kan de informatie hoogst betrouwbaar zijn doch van weinig nut voor gebruikers die hun beslissingen intussen hebben moeten nemen.' (Stramien paragraaf 43). Het nu reeds verschaffen van informatie neemt onzekerheid over de gevolgen van IFRS weg bij gebruikers van jaarrekeningen.

Op grond van het vorenstaande mag worden verwacht dat ondernemingen gebruikers van jaarrekeningen tijdig, dat wil zeggen voor het daadwerkelijke ingangstijdstip van 1 januari 2005, informeren over de effecten van invoering van IFRS.

\section{Definiëring onderzoek}

Het onderzoek betreft allereerst ondernemingen die medio 2004 zijn opgenomen in NextEconomy (NE) en NextPrime (NP). Voorts zijn in het onderzoek betrokken ondernemingen die medio 2004 deel uitmaken van de AMX. Voor beide categorieën geldt dat financiële instellingen buiten beschouwing zijn gelaten. Daarnaast is een willekeurige selectie gemaakt uit andere ondernemingen met een notering aan de Euronext Amsterdam. Hierbij past de kanttekening dat voor ondernemingen die niet zijn opgenomen in NE/NP, geen verplichting geldt uiterlijk bij de halfjaarcijfers 2004 de hierboven bedoelde gegevens te verstrekken.

Tevens zijn buiten beschouwing gelaten ondernemin- gen die rapporteren op basis van US GAAP, daar de additionele informatiewaarde van rapportage op basis van IFRS in deze gevallen veelal beperkt wordt ingeschat.

Met opzet is er van afgezien ondernemingen die deel uitmaken van de AEX in het onderzoek op te nemen. Veelal hebben deze ondernemingen ook elders een rapportageverplichting. Hierdoor verschaffen zij mogelijk uit dien hoofde reeds informatie die (grotendeels) gelijk is aan de verlangde gegevens op basis van IFRS.

Op basis van de hiervoor beschreven criteria bestaat de onderzoeksgroep uit 61 ondernemingen. De zeven ondernemingen die zowel deel uitmaken van de AMX als zijn opgenomen in $\mathrm{NE} / \mathrm{NP}^{3}$ zijn ten behoeve van dit onderzoek ingedeeld bij de AMX-fondsen. De gehanteerde indeling is: 19 ondernemingen uit de AMX, 28 ondernemingen uit het NE/NP-segment en 14 in de categorie overige.

Een aantal standaarden is nog maar recent, vierde kwartaal 2003 en eerste halfjaar 2004, herzien of gepubliceerd. Derhalve is de inventarisatie gebaseerd op de halfjaarberichten 2004 en de jaarrapporten over 2003. Eerdere mededelingen die zijn gebaseerd op een oudere versie van standaarden zijn immers niet meer informatief.

Van de ondernemingen uit de onderzoeksgroep is allereerst nagegaan of zij informatie omtrent de gevolgen van IFRS hebben verstrekt. Vervolgens is onderzocht of deze gevolgen zijn gekwantificeerd dan wel dat het informatie van kwalitatieve aard betreft. De bevindingen zijn vermeld in de bijlage. Voorts is nagegaan welke posten door ondernemingen worden benoemd. In het geval geen melding is gemaakt van gevolgen van invoering van IFRS, is een poging gedaan op basis van eigen inschatting aan te geven welke posten zullen worden beïnvloed.

\section{Vermelding effecten van IFRS}

In tabel 1 zijn de bevindingen met betrekking tot de door ondernemingen gepresenteerde informatie in de halfjaarberichten 2004 en/of de jaarrapporten over 2003 omtrent de gevolgen van invoering van IFRS opgenomen.

Uit deze tabel blijkt dat van de 61 onderzochte ondernemingen nauwelijks meer dan de helft (51\%) melding maakt van de gevolgen van implementatie van IFRS. Van de 28 geselecteerde ondernemingen uit het NE/NP-segment is door tien ondernemingen (36\%) niets vermeld over de invloed van IFRS. Eén onderneming uit deze categorie geeft aan te rapporteren op basis van IFRS. Bij de AMX-fondsen hebben tot op 


\begin{tabular}{|c|c|c|c|c|c|}
\hline Aard van de informatie & $\mathrm{NE} / \mathrm{NP}$ & AMX & Overige & Totaal & \\
\hline Kwalitatief & 10 & 7 & 1 & 18 & $30 \%$ \\
\hline Kwantitatief & 7 & 2 & 1 & 10 & $16 \%$ \\
\hline Indicatief & 1 & 2 & 0 & 3 & $5 \%$ \\
\hline $\begin{array}{l}\text { Subtotaal enige } \\
\text { mededeling }\end{array}$ & 18 & 11 & 2 & 31 & $51 \%$ \\
\hline Geen mededelingen & 10 & 8 & 12 & 30 & $49 \%$ \\
\hline Totaal & 28 & 19 & 14 & 61 & $100 \%$ \\
\hline
\end{tabular}

heden acht ondernemingen (42\%) niets gemeld omtrent de effecten van IFRS. Van de 14 in het segment overige ondernemingen maken slechts twee melding van de invloed van IFRS.

Niet alle ondernemingen geven een verklaring voor het feit dat zij tot op heden nog niets melden omtrent de gevolgen van IFRS. Door enkele ondernemingen wordt als reden aangevoerd, dat nog onlangs een aantal regels zijn veranderd, dan wel dat bepaalde standaarden nog niet vaststaan. Arcadis meldt dat het onderzoek naar de gevolgen van de overgang naar IFRS nog niet is afgerond. De onderneming geeft aan dat daarom nog geen kwantitatieve analyse kan worden verstrekt over het effect van IFRS. Kwalitatieve informatie, bijvoorbeeld in de vorm van een opsomming van posten waarop IFRS met name invloed zal hebben, ontbreekt bij Arcadis eveneens.

Vervolgens is nagegaan of de gevolgen van implementatie van IFRS door ondernemingen zijn gekwantificeerd. Van de 31 ondernemingen die informatie verstrekken over de gevolgen van implementatie van IFRS hebben tien het effect gekwantificeerd. Hiervan behoren er negen tot de NE/NP-fondsen, daar de twee AMXfondsen die kwantitatieve informatie presenteren tevens deel uitmaken van NE/NP. Sligro is de enige onderneming uit de categorie overige ondernemingen die kwantitatieve informatie verstrekt. Daarnaast geven drie ondernemingen indicaties af. $\mathrm{Bij}$ de overige 18 ondernemingen is sprake van kwalitatieve informatieverschaffing.

Uit deze inventarisatie blijkt dat slechts één onderneming uit de onderzoekspopulatie kwantitatieve informatie presenteert en niet tot NE/NP behoort. Een verplichting tot het verstrekken van informatie lijkt een voorwaarde om te rapporteren over de verwachte effecten van de overgang op IFRS. En zelfs dan laat een belangrijk deel van de ondernemingen tot dusver publicatie hierover achterwege.
Wat opvalt is dat zowel in de vakliteratuur (Hoogendoorn, 2003b) als in de populaire financiële pers ${ }^{4}$ het (equivalent van het) woord volatiliteit valt als over IFRS wordt gesproken, maar dat dit begrip nagenoeg ontbreekt in de door ondernemingen gehanteerde bewoordingen.

Overigens wijzen ook ondernemingen die de effecten kwantificeren er veelal op dat een aantal standaarden nog niet bekrachtigd is door de Europese Unie. Bovendien loopt met betrekking tot sommige standaarden nog een discussie over de interpretatie. Als gevolg daarvan geven ondernemingen aan dat uitspraken over de effecten van IFRS op het resultaat en het eigen vermogen voorlopig zijn. In het kader van deze publicatie voert het te ver aan elke vermelding aandacht te besteden. Ter illustratie van de grote verscheidenheid aan mededelingen volgt hieronder een voorbeeld van hetgeen ondernemingen zowel in kwantitatieve, indicatieve als kwalitatieve zin rapporteren.

De BAM Groep meldt de gevolgen van IFRS in hoofdlijnen en tekent daarbij aan dat is uitgegaan van de stand van de IFRS-regelgeving medio 2004. Hierin kunnen nog wijzigingen optreden. Voor een viertal posten uit de jaarrekening worden de effecten met bedragen genoemd. Het betreft:

- niet langer afschrijven op goodwill. Hierdoor komt een kostenpost van circa $€ 29$ miljoen op jaarbasis te vervallen. In plaats daarvan dient jaarlijks een impairment test te worden uitgevoerd;

- hogere waardering van de verplichtingen uit hoofde van toegezegde pensioenaanspraken (defined benefit) in de IFRS-openingsbalans per 1 januari 2004. Naar de huidige inzichten wordt hiertoe een bedrag tussen $€ 150$ miljoen en $€ 200$ miljoen (ná belasting) van het eigen vermogen afgeboekt;

- gewijzigde rubricering van preferente aandelen (€ 200 miljoen), deze zullen in de balans onder het vreemd vermogen worden gepresenteerd. De dividendbetaling wordt onder IFRS in de winst- en verliesrekening als een financiële last verantwoord;

- wijziging in de rubricering van onderhanden werk. Met name de projecten voor derden, waarbij het bedrag van de gefactureerde termijnen de gemaakte kosten overschrijdt, worden per saldo opgenomen onder de kortlopende schulden. Het totaal van de wijzigingen in de balanspost onderhanden werk heeft een balansverlengend effect van $€ 1$ miljard.

Een voorbeeld van een onderneming die indicatieve informatie verschaft, is Wessanen. Deze onderneming 
duidt de invloed van IFRS op het eigen vermogen en resultaten aan met behulp van vijf categorieën bandbreedten uitgedrukt in percentages. Hierbij is de balans samengevat in vijf posten en de resultatenrekening in elf posten. De gehanteerde percentages refereren per balanspost aan het eigen vermogen ultimo 2003 respectievelijk in de resultatenrekening aan de betreffende post voor aanpassing aan IFRS.

Een voorbeeld van kwalitatieve informatieverstrekking betreft Fugro. Deze onderneming meldt dat het ten tijde van het uitbrengen van het halfjaarbericht 2004 niet mogelijk is om een kwantitatieve indicatie te geven van de belangrijkste te verwachten verschillen op het resultaat en vermogen. Wel worden posten in de jaarrekening genoemd waar Fugro op dit moment wijzigingen in de waardering en/of presentatie verwacht ten opzichte van de huidige grondslagen. Genoemd worden pensioenen, opties, financiële instrumenten, goodwill en belastingen.

Voorts zijn de volgende bevindingen het vermelden waard.

Ten Cate geeft aan dat de analyse van de overgang naar IFRS nog niet volledig is afgerond. Op grond van het feit dat de IASB nog steeds wijzigingen doorvoert in de standaarden en het endorsement-proces in de EU nog in volle gang is, heeft Ten Cate besloten om nog geen kwantitatieve toelichting te verstrekken van de impact van IFRS. De onderneming spreekt de verwachting uit dat de rapportage voornamelijk zal worden beïnvloed door de regelgeving met betrekking tot pensioenen. Omtrent deze pensioenverplichtingen, toch niet het meest eenvoudige element van IFRS, meldt deze onderneming vervolgens dat waardering op basis van IFRS leidt tot een toename van deze verplichtingen met $€ 44$ miljoen.

Daarentegen kwantificeert Crown Van Gelder de invloed op eigen vermogen en resultaat per post uit de jaarrekening, evenwel met uitzondering van de verwerking van de positieve invloed van 'defined benefit' pensioenen. De aangevoerde reden daarvoor is dat het nog onzeker is of deze bedragen volgens IFRS kunnen worden opgenomen.

Eén onderneming, Brunel, meldt dat de openingsbalans op basis van IFRS niet zal afwijken van de balans volgens huidige grondslagen.

Een zevental ondernemingen deelt in wisselende bewoordingen mede dat de invloed van IFRS naar verwachting beperkt is, geen materiële gevolgen heeft dan wel dat geen grote effecten worden verwacht. Opmerkelijk is dat twee ondernemingen aangeven dat de effecten van invoering van IFRS in potentie significant zijn, maar dat zij geen indicatie geven, laat staan dit kwantificeren.
Uit de inventarisatie blijkt dat ongeveer de helft van de onderzoekspopulatie een beschrijving geeft van de verwachte effecten van de overgang op IFRS op de beginbalans en de resultaten. De aard van de verstrekte informatie loopt uiteen. Slechts $16 \%$ van de populatie heeft het effect gekwantificeerd.

Voorts blijkt dat de NE/NP-fondsen relatief gezien voorlopen op de andere onderzochte fondsen. Op het eerste gezicht ligt de score van de AMX-fondsen niet ver van die van de NE/NP-fondsen. Dit beeld wijzigt evenwel indien wij de score van de AMX-fondsen corrigeren voor de zeven ondernemingen die zowel deel uitmaken van de AMX als zijn opgenomen in NE/NP. Bij de resterende AMX-fondsen loopt het deel dat niets heeft gemeld in dat geval op van $42 \%$ tot $58 \%$. Bovendien blijkt dat door deze ondernemingen alleen kwalitatieve informatie is gegeven.

\section{5 \\ Posten in de jaarrekening beïnvloed door IFRS}

Aan de hand van de verstrekte informatie is geïnventariseerd welke posten onder IFRS verschillen ten opzichte van de huidige grondslagen. Daarnaast is voor ondernemingen die hierover tot op heden nog niets hebben gemeld, op basis van de gebruikte halfjaarberichten 2004 en/of de jaarrapporten 2003 ingeschat welke posten in de financiële verslaggeving worden beïnvloed.

De in tabel 2 genoemde posten zijn de meest voorkomende posten die worden beïnvloed door toepassing van IFRS. Deze posten worden, met uitzondering van preferente aandelen, reeds genoemd in de door Vergoossen (1999) gemaakte analyse van de gevolgen voor de Nederlandse verslaggevingspraktijk aan de hand van belangrijke of opvallende verschillen die er op dat moment bestonden tussen IAS en de Nederlandse verslaggevingsregels.

Tabel 2. Belangrijkste posten beïnvloed door IFRS

\begin{tabular}{l|l|l|l|l|l|l} 
Jaarrekeningpost & $\begin{array}{l}\text { Frequentie } \\
\text { Vermelding }\end{array}$ & & $\begin{array}{l}\text { Frequentie } \\
\text { geen } \\
\text { vermelding, } \\
\text { wel van } \\
\text { toepassing }\end{array}$ & & $\begin{array}{l}\text { Geen } \\
\text { vermelding, } \\
\text { (mogelijk) } \\
\text { niet van } \\
\text { toepassing }\end{array}$ \\
\hline Goodwill & 23 & $38 \%$ & 16 & $26 \%$ & 22 & $36 \%$ \\
Pensioenen & 22 & $36 \%$ & 8 & $13 \%$ & 31 & $51 \%$ \\
Opties & 13 & $21 \%$ & 9 & $15 \%$ & 39 & $64 \%$ \\
Financiële instrumenten & 12 & $20 \%$ & 6 & $10 \%$ & 43 & $70 \%$ \\
Preferente aandelen & 10 & $16 \%$ & 6 & $10 \%$ & 45 & $74 \%$
\end{tabular}


Onder het IFRS-regime brengt 64\% van de onderzochte ondernemingen niet langer goodwill-amortisatie ten laste van het resultaat. Dit heeft een positief effect op de verantwoorde resultaten. In plaats daarvan komen eventuele in de toekomst noodzakelijke impairmentlasten.

Bij nagenoeg de helft, 49\%, is waardering van toegezegde pensioenaanspraken (defined benefit) aan de orde. De invloed op de winst- en verliesrekening blijft veelal onduidelijk, mede doordat ook met de toegestane corridor wordt gewerkt.

De effecten van personeels- en managementopties zijn door geen enkele onderneming uit de onderzoeksgroep expliciet gekwantificeerd.

Onder financiële instrumenten zijn met name opgenomen rente-instrumenten (interest rate swaps) en valutatermijncontracten. De verwerking van financiële instrumenten volgens IFRS leidt tot een toename van de volatiliteit van het resultaat en eigen vermogen.

Door $26 \%$ van de onderzochte ondernemingen zijn preferente aandelen uitgegeven. Indien deze aandelen onder IFRS kwalificeren als vreemd vermogen kunnen deze niet langer binnen het eigen vermogen worden opgenomen. De gewijzigde presentatie van preferente aandelen heeft onder meer effect op door banken gehanteerde ratio's als bijvoorbeeld Debt/ Equity (rentedragend vreemd vermogen/eigen vermogen). De dividendbetaling op deze preferente aandelen dient onder IFRS te worden aangemerkt als financiële last en maakt derhalve deel uit van de winstbepaling. Deze presentatie beïnvloedt rentedekkingsratio's die op basis van de jaarrekening worden berekend. Met betrekking tot preferente aandelen merkt Simac op, dat het dividend op de preferente aandelen voortaan ter vaststelling van de algemene vergadering van aandeelhouders is. De preferente aandelen bij deze onderneming kwalificeren daardoor volgens deze onderneming als eigen vermogen. Ook Priority Telecom merkt op er aan te werken de overeenkomst met betrekking tot de preferente aandelen zodanig aan te passen, dat deze ook in de toekomst als eigen vermogen classificeren.

Daarnaast is bij zes ondernemingen uit de onderzoeksgroep de balanspost onderhanden werken van invloed. Het gaat hier niet alleen om effecten van waarderingswijzigingen maar ook om een andere wijze van presenteren. Onder IFRS worden stringentere voorwaarden gesteld aan het activeren van kosten. De invloed op de waardering van onderhanden werken is naar verwachting veelal beperkt. De wijziging in de presentatie heeft daarentegen significante invloed. Het betreft hier met name projecten voor derden waarvan de gedeclareerde termijnen de waarde van het verrichte werk overtreffen. Deze worden aan de passiefzijde onder de kortlopende schulden gerubriceerd, in plaats van saldering met de overige onderhanden projecten aan de actiefzijde, en hebben daardoor een balansverlengend effect. Op basis van de verstrekte kwantitatieve informatie kan worden geconcludeerd dat de solvabiliteitsratio hierdoor in negatieve zin wordt beïnvloed.

Onder de overige elementen van de jaarrekening die door IFRS worden beïnvloed is driemaal de samenstelling van de consolidatiekring genoemd. Voorts is er een tweetal ondernemingen die latente belastingen waarderen op contante waarde waar IFRS nominale waarde verlangt.

De verwerking van financiële instrumenten volgens IFRS alsmede eventuele goodwill impairment-lasten zullen leiden tot een toename van de volatiliteit van de resultaten van ondernemingen.

\section{Samenvatting en conclusie}

Uit het onderzoek blijkt dat een krappe meerderheid van de ondernemingen informatie verstrekt over de gevolgen van invoering van IFRS en daarmee gebruikers voorbereidt op een ander beeld dat de jaarrekening onder IFRS geeft van vermogen en resultaat. Slechts 16\% heeft het effect gekwantificeerd en stelt daardoor gebruikers in staat een nieuw referentiekader te vormen. Dit is een relatief geringe groep, waardoor voor gebruikers de mogelijkheid om door onderlinge vergelijking een referentiekader te vormen beperkt is. De verwachting dat ondernemingen gebruikers tijdig informeren over de gevolgen van IFRS is niet uitgekomen.

Op basis van het Euronext marktreglement mocht worden verwacht dat ondernemingen uit het NE/NPsegment uiterlijk in het halfjaarbericht 2004 een toelichting met een beschrijving van de verwachte effecten van de overgang op IFRS op de beginbalans en de resultaten zouden publiceren. Ondanks deze verplichting heeft 35\% van de ondernemingen uit deze categorie tot dusver nog geen informatie verstrekt.

Uit de onderhavige inventarisatie komt het beeld naar voren dat indien al informatie wordt verstrekt, de mededelingen over de impact van IFRS nogal kwalitatief van aard zijn. Op het punt van kwantitatieve informatie scoren de ondernemingen uit het NE/NPsegment beter dan de AMX-fondsen.

Voorts blijkt dat ondernemingen overeenkomsten herzien met betrekking tot preferente aandelen om deze ook in de toekomst als eigen vermogen te kun- 
nen presenteren. Deze inspanning is opmerkelijk daar het hier veeleer een rubriceringswijziging betreft dan dat de onderliggende karakteristieken, met inbegrip van cashflows, worden aangetast. Dit vormt een indicatie dat ondernemingen mogelijk doende zijn overeenkomsten zodanig om te vormen, dat deze IFRS-proof zijn en niet leiden tot een (substantiële) aanpassing van de te rapporteren gegevens.

Met betrekking tot de ondernemingen die geen gegevens verstrekken, komt allereerst de vraag op of dit voortvloeit uit het nog niet afgerond zijn van het interne implementatietraject. Bezien vanuit het perspectief van gebruikers is de openheid van twee ondernemingen die melden dat de overgang naar IFRS nog niet volledig is afgerond, lovenswaardig. Vervolgens rijst de vraag of en zo ja in welke mate het niet rapporteren is toe te schrijven aan recent gewijzigde regelgeving. Dit feit en het argument dat standaarden nog niet zijn bekrachtigd door de Europese Unie wordt ook aangevoerd als motief om kwantificering van de effecten achterwege te laten. Het vorenstaande illustreert dat het late moment van aanpassen van de IFRS-standaarden in combinatie met de toepassing met ingang van de jaarrekening 2005 tot knelpunten leidt. Dit betekent in de praktijk onvolledigheid in de rapportering over IFRS en niet tijdig informeren door ondernemingen over de gevolgen van invoering van IFRS.

Ook vanuit de accountantsberoepsgroep wordt dit geluid vernomen. Zo stelt Hoogendoorn (2004, p. 33) dat '... menige onderneming in Europa niet in staat zal zijn om met terugwerkende kracht vanaf 1 januari 2004 voldoende betrouwbare informatie aan te leveren die in volledige overeenstemming is met IFRS. Dit kan de ondernemingen, gezien de late vaststelling van de definitieve regels en de enorme veranderingen die deze regels met zich brengen, nauwelijks kwalijk worden genomen.'

Door alle aandacht en energie die opstelling van standaards en implementatie daarvan vraagt, lijken de belangen van gebruikers van jaarrekeningen uit beeld te geraken. Naar mate het jaar van de 'waarheid', 2005, dichterbij komt, dient communicatie met gebruikers over de gevolgen van IFRS een punt van aandacht te zijn. Of is de vraag hoe gebruikers op IFRS-opstellingen reageren geen issue? Het beeld dat uit dit onderzoek naar voren komt is dat de situatie voor gebruikers niet helder is.

\section{Literatuur}

Botosan, C.A., (1997), The effect of disclosure level on the cost of equity capital, in: The Accounting Review, vol. 72, no. 3, pp. 323-349.

Botosan, C.A. en M.A. Plumlee, (2002), A re-examination of disclosure level and the expected cost of equity capital, in: Journal of Accounting Research, vol. 40, no. 1, pp. 21-40.

Camfferman, K. en F. van der Wel, (2003), Reële waarde in de regelgeving, in: Maandblad voor Accountancy en Bedriffseconomie, jg. 77, nr. 9, pp. 379-386.

Euronext Rule Book I (01), (2003), Rule7203/3.

Europese Gemeenschappen, (2002), Verordening (EG) Nr. 1606/2002 van het Europees Parlement en de Raad van 19 juli 2002 betreffende toepassing van internationale standaarden voor jaarrekeningen, in: Publicatieblad van de Europese Gemeenschappen, L 243/1.

Francis, J., R. LaFond, P.M. Olsson en K. Schipper, (2004), Costs of equity and earnings attributes, in: The Accounting Review, vol. 79, no. 4, pp. 9676-1010.

Hoeven, R.L. ten, (2003), Het waardeconcept binnen IFRS, in: Accounting, nr. 5, pp. 3-8.

Holterman, W., (2002), Transparantie en de marktwaarde van de aandelen van een onderneming, in: Maandblad voor Accountancy en Bedrijfseconomie, jg. 76, nr. 12, pp. 574-582.

Hoogendoorn, M.N., J. Klaassen en F. Krens, (2004), Externe verslaggeving in theorie en praktijk, vierde druk, Reed Business Information bv, 's-Gravenhage.

Hoogendoorn, M.N., (2004), Regels over regels, Kluwer.

Hoogendoorn, M.N., (2003a), IFRS als krachtproef voor het accountantsberoep, in: Maandblad voor Accountancy en Bedrijfseconomie, jg. 77, nr. 11, pp. 480-481.

Hoogendoorn, M.N., (2003b), Reële waarde, jaarrekening en ondernemingsbeleid, in: Maandblad voor Accountancy en Bedrijfseconomie, jg. 77, nr. 9, pp. 387-396.

Klaassen, J. , M.N. Hoogendoorn en G.G.M. Bak, (2001), Externe verslaggeving, Stenfert Kroese.

Marseille,E. en P.Koster, (2003), Toezicht op financiële verslaggeving, in: Maandblad voor Accountancy en Bedrijfseconomie, jg. 76, nr. 12, pp. 583-588.

Ouden, G.J. den, (2004), Gebruikers: Inactieve Figuranten in Raadselachtig Scenario?, in: Verslag Limpergdag 2004, Limperg Instituut, Amsterdam.

Raad voor de Jaarverslaggeving, (2003), Richtlijnen voor de jaarverslaggeving, editie 2003, Kluwer, Deventer.

Vergoossen, R.G.A., (2003), Nieuwe regels jaarverslag dwingen tot cultuuromslag, in: Het Financieele Dagblad 2 juni 2003.

Vergoossen, R.G.A., (1999), International Accounting Standards en de gevolgen voor de verslaggeving in Nederland, in: Maandblad voor Accountancy en Bedrijfseconomie, jg. 73, nr. 9, pp. 450-460.

\section{Noten}

1 Verordening Nr. 1606/2002 van 19 juli 2002.

2 Opgenomen in Richtlijnen voor de jaarverslaggeving.

3 Het betreft BAM Groep, Heijmans, Nutreco, Stork, Vedior, Vopak en Wessanen.

4 FEM Business, 30 oktober 2004, spreekt bijvoorbeeld van winstcijfers die bedrijven rapporteren die door nieuwe internationale boekhoudregels in de toekomst veel heftiger gaan schommelen dan nu het geval is. 


\section{Bijlage}

\section{Overzicht van vermeldingen van gevolgen IFRS}

\begin{tabular}{|c|c|c|c|c|c|c|}
\hline \multicolumn{2}{|c|}{ AMX } & \multirow{2}{*}{$\begin{array}{l}\text { Vermelding } \\
\text { gevolgen IFRS }\end{array}$} & \multicolumn{4}{|c|}{ Aard van de informatie } \\
\hline & & & \multirow[t]{2}{*}{ Kwalitatief } & \multirow[t]{2}{*}{ Kwantitatief } & \multirow[t]{2}{*}{ Indicatief } & \multirow{2}{*}{$\begin{array}{l}\text { Geen } \\
x\end{array}$} \\
\hline 1 & Air France & & & & & \\
\hline 2 & BAM & $x$ & & $x$ & & \\
\hline 3 & Boskalis Westminster & & & & & $x$ \\
\hline 4 & Corus & $x$ & $x$ & & & \\
\hline 5 & CSM & & & & & $x$ \\
\hline 6 & Fugro & $x$ & $x$ & & & \\
\hline 7 & Heijmans & $x$ & & $\mathrm{x}$ & & \\
\hline 8 & HunterDouglas & & & & & $x$ \\
\hline 9 & Imtech & & & & & $x$ \\
\hline 10 & Laurus & $x$ & $x$ & & & \\
\hline 11 & LogicaCMG & & & & & $x$ \\
\hline 12 & Nutreco & $x$ & $x$ & & & \\
\hline 13 & Océ & $x$ & $x$ & & & \\
\hline 14 & Royal P\&O Nedlloyd & & & & & $x$ \\
\hline 15 & Randstad & $x$ & $x$ & & & \\
\hline 16 & Stork & $x$ & & & $x$ & \\
\hline 17 & Vedior & $x$ & $x$ & & & \\
\hline 18 & Vopak & & & & & $x$ \\
\hline \multirow[t]{2}{*}{19} & Wessanen & $x$ & & & $x$ & \\
\hline & & 11 & 7 & 2 & 2 & 8 \\
\hline
\end{tabular}

\section{Next Economy en NextPrime (niet in AMX)}

\begin{tabular}{|c|c|c|c|c|c|c|c|}
\hline 1 & Accell & & & & & & $x$ \\
\hline 2 & Amstelland & $\mathrm{x}$ & & & $x$ & & \\
\hline 3 & Antonov & & & & & & $x$ \\
\hline 4 & Arcadis & & & & & & $\mathrm{x}$ \\
\hline 5 & Athlon & $\mathrm{x}$ & & & $x$ & & \\
\hline 6 & Beter Bed & $\mathrm{x}$ & & & $x$ & & \\
\hline 7 & Blue Fox & & & & & & $x$ \\
\hline 8 & Brunel & $\mathrm{x}$ & & & $\mathrm{x}$ & & \\
\hline 9 & Kon Ten Cate & $\mathrm{x}$ & & & $\mathrm{x}$ & & \\
\hline 10 & Crown Van Gelder & $\mathrm{x}$ & & & $x$ & & \\
\hline 11 & Ctac & $\mathrm{x}$ & & $x$ & & & \\
\hline 12 & DPA & & & & & & $x$ \\
\hline 13 & Eriks & $\mathrm{x}$ & & & & $\mathrm{x}$ & \\
\hline 14 & Gamma & $\mathrm{x}$ & & $x$ & & & \\
\hline 15 & Grontmij & $\mathrm{x}$ & & $\mathrm{x}$ & & & \\
\hline 16 & HITT & & & & & & $x$ \\
\hline 17 & Kendrion & $\mathrm{x}$ & & $x$ & & & \\
\hline 18 & Magnus & & & & & & $x$ \\
\hline 19 & Mc Gregor Fashion & $\mathrm{x}$ & & $\mathrm{x}$ & & & \\
\hline 20 & Petroplus & $\mathrm{x}$ & & $\mathrm{x}$ & & & \\
\hline 21 & Pharming & $x$ & & & $x$ & & \\
\hline 22 & Priority Telecom & $x$ & & $\mathrm{x}$ & & & \\
\hline 23 & RotoSmeetsDeBoer & & & & & & $x$ \\
\hline 24 & Seagull & & & & & & $x$ \\
\hline 25 & Simac & $\mathrm{x}$ & & $\mathrm{x}$ & & & \\
\hline 26 & SNT & $x$ & & & $x$ & & \\
\hline 27 & Tie & & & & & & $x$ \\
\hline \multirow[t]{2}{*}{28} & Twentsche Kabel & $\mathrm{x}$ & & $x$ & & & \\
\hline & & 18 & $64 \%$ & 10 & 7 & 1 & 10 \\
\hline
\end{tabular}


EXTERNE VERSLAGGEVING

\begin{tabular}{|c|c|c|c|c|c|c|c|}
\hline \multirow{2}{*}{\multicolumn{2}{|c|}{ Overige }} & \multirow{2}{*}{\multicolumn{2}{|c|}{$\begin{array}{l}\text { Vermelding } \\
\text { gevolgen IFRS }\end{array}$}} & \multicolumn{4}{|c|}{ Aard van de informatie } \\
\hline & & & & Kwalitatief & Kwantitatief & Indicatief & Geen \\
\hline 1 & Aalberts Industries & & & & & & $x$ \\
\hline 2 & Ballast Nedam & & & & & & $\mathrm{x}$ \\
\hline 3 & Blydenstein-Willink & & & & & & $\mathrm{x}$ \\
\hline 4 & Draka & & & & & & $\mathrm{x}$ \\
\hline 5 & Exact & & & & & & $\mathrm{x}$ \\
\hline 6 & Grolsch & & & & & & $\mathrm{x}$ \\
\hline 7 & Ordina & $\mathrm{x}$ & & $\mathrm{x}$ & & & \\
\hline 8 & PinkRoccade & & & & & & $\mathrm{x}$ \\
\hline 9 & RoodTesthouse & & & & & & $\mathrm{x}$ \\
\hline 10 & Sligro Food Group & $x$ & & & $\mathrm{x}$ & & \\
\hline 11 & De Telegraaf & & & & & & $x$ \\
\hline 12 & Unit 4 Agresso & & & & & & $\mathrm{x}$ \\
\hline 13 & Univar & & & & & & $x$ \\
\hline \multirow[t]{2}{*}{14} & Wegener & & & & & & $x$ \\
\hline & & 2 & $14 \%$ & 1 & 1 & 0 & 12 \\
\hline 61 & Totaal & 31 & $51 \%$ & 18 & 10 & 3 & 30 \\
\hline
\end{tabular}

